This item was submitted to Loughborough's Research Repository by the author.

Items in Figshare are protected by copyright, with all rights reserved, unless otherwise indicated.

\title{
Sport, fiction and sociology: novels as data sources
}

PLEASE CITE THE PUBLISHED VERSION

http://dx.doi.org/10.1177/1012690215617758

\section{PUBLISHER}

Sage / @ The Authors.

\section{VERSION}

AM (Accepted Manuscript)

\section{PUBLISHER STATEMENT}

This work is made available according to the conditions of the Creative Commons Attribution-NonCommercialNoDerivatives 4.0 International (CC BY-NC-ND 4.0) licence. Full details of this licence are available at: https://creativecommons.org/licenses/by-nc-nd/4.0/

\section{LICENCE}

CC BY-NC-ND 4.0

\section{REPOSITORY RECORD}

Bairner, Alan. 2019. "Sport, Fiction and Sociology: Novels as Data Sources". figshare. https://hdl.handle.net/2134/19592. 


\title{
Sport, fiction and sociology: novels as data sources
}

\section{Alan Bairner}

\section{Loughborough University, UK}

\begin{abstract}
This paper is primarily concerned with the types of data that are of value to sociologists - in this instance, particularly to sociologists of sport. It is argued here that we can and should add works of fiction to the more commonly accepted data sources. Whilst most academic writers may be cautious about the excessive use of invention even in personal narratives, others are less diffident. The paper examines representations of sport in fiction with specific reference to three novels, their central characters, and the insights provided by their fictional beings into the relationship between sport, individuals and society. The novels selected as evidence are Robert Coover’s The Universal Baseball Association, inc. J. Henry Waugh PROP (UBA), Richard Ford's The Sportswriter (TS) and Chad Harbach's The Art of Fielding
\end{abstract} (TAF). Based on the identification of emerging themes in the novels, and the application of relevant sociological concepts - anomie, alienation and figurations - it is argued that, although the novels' authors are not sociologists, they could be and although the stories which they tell are not true, they too could be. It is these 'facts' that makes them valuable sources of data.

\section{Keywords}

Sports fiction; methodology; sociological concepts: fans; sports writers; athletes 


\section{Introduction}

Relatively early indications that works of fiction might offer ways of looking at sport emerged at a conference held jointly in 1981 by the Centre for Contemporary Cultural Studies and the Department of Physical Education in the University of Birmingham, United Kingdom, at which a number of studies were presented on the ways in which sport is treated in novels (Jenkins and Green, 1981). This led Hollands (1988: 213) to refer to 'a burgeoning interest in the relationship between sport, culture and literature'. However, whilst culture, understood in various ways, has remained an important element in the study of sport, literature has been relatively ignored. Whilst Mary Jo Kane (1998) subsequently noted that young adult sports fiction offered illuminating insights into the sports world of adolescent females, her main aim was not to reveal works of fiction to be useful sources of data but rather to problematize the sports fiction available to young female readers as insidiously disempowering.

In recent years, it has been sports history, rather than the sociology of sport, that has taken up the challenge of using fiction in general and the novel in particular as a research resource. 'In the wake of recent challenges to historical orthodoxy', Hill and Williams (2009: 130) argue, ‘there is a case for considering afresh some of our approaches'. Indeed, Hill (2007) had already done so with a collection of essays published two years earlier. Hughson’s (2010, 2011) work on art and, in particular, Olympic posters is also exemplary of such a new 
approach to data sources and film too has proved to be a valuable medium in this respect (Crosson, 2013; Rinehart, forthcoming).

With specific reference to sport history, Hill and Williams (2009: 131) argue that 'while we may debate therefore whether a given text uses sport for narrative flavouring, is a parody or a fully-blown "sports story”, it is rare that such examples would have a resonance for those without a passing literacy in “reading” the game'. Thus, as Bateman (2015: 383) notes, 'Following the lead of American academics such as Michael Oriard and Christian Messenger, a number of sports historians have in recent years begun to look at imaginative literature as an important mediator of sport'. It is in this spirit, as Johnes (2007) suggests, that novels should be approached as potential sources in sport history. But what works for sports history may not work for sociology. How sociological, for example, are works of fiction? They can, of course, be interpreted sociologically. The focus of this essay, however, is not on 'the social relations of literary production’ (Bennett, 2010: 254) or ‘the sports novel as commodity’ (Hollands, 1988: 2015) but rather on the sociological insights that the works themselves can offer and the sociological concepts that help to strengthen those insights.

\section{Sociology and fiction}

In literary studies, the sociology of literature has relatively little traction (English, 2010). There are, it is true, sociological strains in literary studies. But what about literary strains in sociological studies? English (2010: xx) makes the case for greater interaction between the two fields of inquiry.

There are so many intersections and openings, so many parallel projects of research, so many forms of literary study that rely on sociological thought, and so many forms of sociology that confront 
the literariness of their own objects and procedures, that the real question today is not whether, or even why, but how. How can sociology and literature best take advantage - institutionally as well as intellectually - of their polymorphic and often underacknowledged but nonetheless durable partnership.

An obstacle exists, however, in the desire of many sociologists to demonstrate not that they are revealing absolute truths but that they are, at the very least, searching for multiple truths or approximations to the truth whereas writers of fiction are sometimes perceived to be simply 'making things up'. Literature has certainly been described as a fabrication (Bennett, 2010). Yet, the former Anglican Bishop of Edinburgh, Richard Holloway (2012) argues that great fiction explores the truth better than anything. The point, therefore, is not to pursue a sociology of literature but 'to see what happens when sociology and literature are reciprocally illuminated by their dissimilar, yet comparable, approaches to the same site' (Alworth, 2010: 302). Therefore, much depends upon how we actually use literature and, more specifically, how we read works of fiction sociologically.

According to de Certeau (1988: xxi), the reader of a novel may be likened to someone who rents a house insofar as s/he makes texts 'habitable' and, in so doing, 'transforms another person’s property into a space borrowed for a moment by a transient'. There is a marked difference, however, in furnishing a property for which one already owns appropriate furniture and one for which there is a need to start with little or nothing. This raises fundamental questions about the relationship between authors, readers and texts which I have addressed intermittently over many years (Bairner, 1996, 2000, 2009, 2011). As sociologists of sport, we bring something to our reading (or renting) that other readers may well lack. 
In many respects, this paper has as much to do with methodology as with the content of specific novels. In discussing the use of fictional methods in ethnographic research, Rinehart (1998) identified three kinds of writing - academic writing that seeks to replicate some sort of truth, fiction which can be based on actual events but is often the product of the writer's interpretation of actual or imagined events, and fictional ethnography which 'combines the realist goals of academic ethnography and fiction but with an eye to both instruction and feeling' (p. 204). The latter, in the form of creative nonfiction, has become an increasingly accepted means of exploring the whats, the whys and the hows and is used to complement and, in some cases, supplement traditional academic writing (Sparkes and Smith, 2013). The exponents of this approach argue that creative nonfiction 'tells a story that is grounded in research data and draws on literary conventions’ (Smith et al, 2016: 59). One should also mention in this context the use of narrative more generally and also autoethnography. In storytelling sociology, 'the measure of the truth is judged not by conventional scientific standards of validity and reliability but by the power of stories to evoke the vividness of lived experience' (Berger and Quinney, 2005: 9). In this way, storytelling is recognised as a legitimate form of research (Koch, 1998) as exemplified by Denison (1996) amongst others. The emphasis remains throughout, however, according to Cheney (2001), on establishing facts. But, in light of the criteria invoked to support the use of creative nonfiction and storytelling, is there a place in the sociology of sport for authors of fiction whose primary objective in writing is not sociological?

Whilst most academic writers may be cautious about the excessive use of invention even in personal narratives, others are less diffident. According to novelist Jean-Claude Izzo (2013: 38), the chronicler of Marseilles’ criminal underbelly, 'imagination is a reality, sometimes 
more real than reality itself'. In similar vein, journalist Joe Queenan (2010: 151) writes, 'Just because something isn’t true doesn't mean you shouldn't believe in it'. We are not talking here about the difference between truth and lies but about 'different sorts of truth' (Maitland, 2012: 14) or of verisimilitude as a way of presenting truth(s). As for comparisons between fiction and creative nonfiction, and setting to one side any suggestion that either approach can uncover absolute truths, it would be wrong to deny that novelists are also researchers or that their approach is less likely to offer insights into society than more conventional data collection presented as creative nonfiction.

To what extent then does sports fiction meet the challenge of uncovering sociologically valuable insights and confirming the value of key sociological concepts? Is it possible that the central characters in the three novels that are discussed in this paper can fulfil the role of participants in a sociological study of sport?

\section{Sports fiction}

Sports fiction includes novels, short stories, poems and drama in which sport is a significant element but is not necessarily the sole focus. Thus, novels that explore a multiplicity of other themes can still be described as sports fiction. Indeed, Philip Roth’s suggestively titled The Great American Novel (1995) is a good example of the genre, given that it tells the story of Gil Gamesh, the only baseball pitcher who ever 'literally' tried to kill the umpire but can also be regarded as an attempt to live up to its title.

Literature about sport in late nineteenth century Britain focused increasingly on the martial aspect of team games, stressing the role athleticism could play in defending the empire and training officials to administer it (Ryan, 2012). With reference to more recent cricket fiction, 
Tadié (2010: 693) argues that 'literature about cricket does not merely portray the game, but defines our perception of it...'. Cricket fiction offers insights into a range of sociologically interesting themes, including national identity, post-colonialism and diaspora (Kesavan, 2012). Similarly, literature has provided insight into, and served to influence, the relationship between sport and nationalism in Australia (Horton, 2012). Football fiction, although less well developed at least in terms of quality and range, offers similar potential in many parts of the world (McGowan, 2015).

Although there is an increasing amount of sports fiction as defined above, much of it is still produced as it was throughout the twentieth century by American authors fascinated in particular by the place of baseball in the national imaginary. Shivani (2014: 45) exaggerates when claiming that 'It’s a creed among the nation’s intellectuals to hold baseball in high regard, as though the American dream and baseball were inseparable'. Nevertheless, there are plenty of examples that support this thesis - Bernard Malamud's The Natural (1967), George Plimpton's The Curious Case of Sidd Finch (1988) and Joseph M. Schuster's The Might Have Been (2012) and many more and, for young adults, Michael Chabon’s Summerland (2008) and Jennifer E. Smith's The Comeback Season (2010). Also worthy of mention is Don Delillo’s Underworld (2003) which opens during a game between the New York Giants and the Brooklyn Dodgers which the Giants win 5-4, thereby capturing the National League with a three run homer in the ninth inning resulting from what baseball fans came to remember as 'the shot heard around the world'.

Other sports have received considerably less attention from American writers although Robert Coover (1989) and Don Delillo (1996) are notable exceptions having both written about American football as well as about baseball. It should come as no surprise, therefore, 
that two of the novels to be discussed in this essay centre around baseball whilst the other is concerned with American sport more generally.

According to Lucien Goldmann (1975: 8), there is nothing surprising about the creation of the novel as a literary genre.

Its apparently extremely complex form is the one which men live every day, when they are obliged to seek all quality, all use value in a mode degraded by the mediation of quantity, of exchange value - and this in a society in which any effort to orientate oneself directly towards use value can only produce individuals who are themselves degraded, but in a different mode, that of the problematic individual.

This paper examines three representations of sport in the novel, each of them featuring problematic, although in certain respects representative individuals. The aim is to identify the insights provided by these fictional beings into the relationship between sport and society and to consider how these insights can be expanded and explicated through reference to the concepts of anomie, alienation and figurations.

\section{Three novels}

Mizruchi (1998: 3) argues that 'Literature teaches us how to read the past' - hence the literary turn in sport history. Let us see then if it can also help us to read the present and the recent past sociologically. The novels selected as evidence are Robert Coover's The Universal Baseball Association, inc. J. Henry Waugh PROP (UBA), Richard Ford's The Sportswriter (TS) and Chad Harbach's The Art of Fielding (TAF) 1 These works have been 
selected as being examples of a genre rather than as ideal types. However, respectively they address fandom, journalism and athleticism which are taken to be three key elements in any analysis of the ways in which sport is practised and consumed. The authors are American and the subject matter American sport. Their novels have been 'rented' for present purposes, to invoke de Certeau's term, by a non-American who has never played either baseball or American football - a necessary admission given the emphasis placed in this discussion on subjective readings of data.

\section{Novelists as gatekeepers}

According to Goldmann (1975: 167-8), 'the novel with a problematic hero is, by its very structure, critical and realistic’. In each of the selected novels, the key protagonists are undeniably problematic albeit in very different ways. What remains to be demonstrated, however, is whether their portrayal is sufficiently critical and realistic to serve as data for sociological analysis.

'When, in 1835', Schwartz (1987: 135) writes, ‘Abner Doubleday didn’t invent the game of baseball in Cooperstown, Ohio, little did he know that he was fueling the imaginations of several postmodernist writers' (my emphasis)). Although Caldwell (1987: 162) argues that 'The true subject of Coover's novel is not the playing of baseball but the making of fiction', this does not mean that it is not a novel about sport. Indeed, as Caldwell (1987:163) himself admits, 'few literary works “about” baseball reveal as much about the nature of sport as this one'. Sports fandom has received considerable attention from sociologists of sports arguably, not least, because fans are relatively accessible and, for the most part, willing to talk, often at 
length, about their fandom. This alone, however, might suggest that they are not the true obsessives, the ones like Henry Waugh who, given their inability to sustain normal social relations, are unlikely to speak to researchers. Despite his relative isolation, Waugh knows about those other sports fanatics, as does his neighbourhood friend, Hettie, who probably thinks that Henry is 'one of those ball-park zealots who went crazy every season during the World Series and got written up as a character - the perennial krank - in the newspapers, and Henry never told her otherwise’ (UBA, p. 22). In creating Waugh, however, Coover provides us with a rare opportunity to witness the extreme end of fandom which is perhaps best described as a descent into madness for, as Hume (1979: 136) notes, 'The insanity of Henry's commitment to the game world is not in doubt'.

Johnson (2007: 45) suggests that 'Despite the popularity of Richard Ford's The Sportswriter and the fact that sporting figures and references to sport occur throughout Ford's fiction, few readers would characterize that fiction as about sport' (original emphasis). Much depends, I would argue, on who the reader (or renter) is. Whilst The Sportwriter is not a book about sport alone, sport is undeniably a central theme. Indeed, when making a noble attempt to depict Frank Bascombe as a representative American everyman, despite the fact that 'race, class and gender differences will stand between him and a large number of his fellow US citizens', Abarrio (2014: 52) misses the opportunity to identify sport as one element in Bascombe’s life which, more than most, provides evidence of his everyman status (my emphasis).

As Brooks (2009: 845) observes, Bascombe 'finds in sports and sports writing an escape from the implications of a pragmatist's view of the world'. Bascombe does not speak for all 
sports writers but how many of us will ever have an opportunity to plumb the depths of sports writers' innermost feelings as opposed to interviewing them for insights into the building of new stadia, corruption within FIFA, or the latest doping scandal? Would they acknowledge, as Bascombe does, that life is not a game, hence the problems which face failed or retired athletes that are addressed 'directly and extensively' in The Sportswriter (Brooks, 2009: 847)?

Elite athletes are notoriously difficult for researchers to access or to get valuable data from even if one is able to circumvent the firewall erected by agents, coaches, mangers sponsors and PR companies that surrounds them. Just as Henry Waugh does not represent all sports fans and Frank Bascombe is not every sports journalist, so Henry Skrimshander is not representative of all college athletes. In many respects, indeed, his story is the least critical and the least realistic of the three. McLaughlin (2013: 286) comments that if the denizens of his college 'seem familiar to the point of tedium, it's because Hollywood films, TV movies of the week, and soap operas have cultivated those fields for years to less and less yield'. Shivani (2014: 43) is even more dismissive, writing that 'While borrowing the gist of the campus novel, the baseball novel, and the gay novel, Harbach has done nothing less than strip each of the three genres of subversive content, ending up with the shells of three familiar conventions but none of their angst'. Shivani (2014: 46) also argues that 'Henry Skrimshander is not haunted by any demons’ as if losing one’s touch, as happens to Skrimshander, is not a powerful enough demon for any athlete. In fact, Shivani (2014) further claims that his loss of touch is inexplicable, presumably without any awareness of the sociological literature on the social dislocation of sport stars and its potential ramifications (Whannel, 2002). Sport has taken Skrimshander from one world to a very different one; his need to perform to the best of his ability is all that stands between him and a return to his 
former life. At the very least, this is a partial explanation of why he loses his touch and also, perhaps, why Harbach, his creator and, by extension, his fan, insists that he regain it.

\section{The fan}

According to Schwartz (1987: 145), Robert Coover 'plays out the history of the western world through baseball and does so in language that captures the fan's enthusiasm for the sport'. Coover's (1992) eponymous protagonist, in The Universal Baseball Association, inc. J. Henry Waugh PROP, is an unhappy and increasingly unsuccessful accountant whose obsession is baseball, not as someone who attends games regularly - 'Communion with those crowds still left Henry alone. Real baseball gave him no creative role’ (Hume, 1979: 139) but as the inventor of his own league, consisting of eight-teams and curated by Waugh over 157 seasons, in which results and individual performances are dictated by the throw of the dice.

Waugh had always played games - 'all on paper of course' (UBA, p. 44). But it is to baseball that he returns, fascinated as he is, like many fans, by its stats: 'Nothing like it really. Not the actual game so much - to tell the truth, real baseball bored him - but rather the records, the statistics, the peculiar balances between individual and team, offense and defense, strategy and luck, accident and pattern, power and intelligence' (UBA, p. 45). Waugh reflects nevertheless on the National Pastime: 'Funny thing about both country music and baseball with its “village greens”: they weren’t really country, not since they got their new names anyway, but urban. Kid stuff, dreams of heroism and innocence, staged by pros and turned into big business' (UBA, p. 36). 
What Waugh enjoys most is recording the history of the league: 'Into the book went the whole UBA, everything from statistics to journalistic dispatches, from seasonal analyses to general baseball theory. Everything, in short, worth keeping' (UBA, p. 55). Henry is aware that he is making more and more mistakes at work such is his focus on his league and its history. But his obsession is such that he can do nothing to alter the situation. Even in the early hours of an autumn night, it is summer for Waugh: 'Green fields and hot suns and shirtsleeved fanatics out on the bleaching boards, last to give it up and go home; he turned back to the table' (UBA, p. 129). Like most sports fans, he also has a favourite player, in his case Damon Rutherford, who, at the start of the novel, pitches a perfect game. Subsequently Rutherford is killed by a bean-ball and his ‘death’ profoundly affects Waugh. Although the players, coaches and owners appear to have lives of their own, Waugh intervenes in his own game, no longer leaving everything to chance, in order to exact revenge on the player responsible for Rutherford's death. His job, his relationships, few as they are, and eventually his sanity are all sacrificed. 'It’s all over, he realized miserably, finished. The Universal Baseball Association, proprietor left for parts unknown’ (UBA, p. 199).

Although the concept of anomie has gone out of favour in recent times, it surely helps us to understand Waugh in social as opposed to solely individual psychological terms. For example Robert Merton’s (1938) ‘Social Structure and Anomie’ sought to link Durkheim’s theory of unattainable desires to the American success ethic in order to suggest the anomic character of US society. Merton’s (1938: 186) aim was ‘to discover how social structures exert a definite pressure upon certain persons to engage in non-conforming rather than conforming conduct'. Waugh is such a person. He is the owner of a valued object in keeping with the meritocratic values that his society purports to valorise but he has become so only at the expense of almost completely disassociating himself from that society. Indeed, in a society that has often been 
represented as lacking organic solidarity, Waugh is 'bowling alone’ (Puttnam, 2001) or, in his case, 'playing baseball alone’.

\section{The sportswriter}

In The Sportswriter, Richard Ford introduces his most enduring character, Frank Bascombe, an aspiring novelist turned sports writer. It has been argued that 'Frank Bascombe represents an embodiment of a mainstream US national identity' (Abarrio, 2014: 58). His background is resolutely Middle American: 'My parents were rural Iowans who left farms near the town of Keota and moved around a lot as young marrieds, ending finally in Biloxi, Mississippi, where my father had some work that involved plating ships with steel at the Ingalls ship-building company, for the Navy, which he'd served in during the war' (TSS, pp. 30-31). He thinks of himself as a typical American man 'an ordinary-looking Joe in a crew-neck sweater, chinos and a John Deere Tractor cap I'd affected when I got to Berkshire' (TSS, p 232). He hears typical Sunday sounds: 'Someone raking spring leaves in a nearby yard, finishing a chore begun months ago; a single horn blat (sic) from the first train down - moms and dads early for services at the Institute' (TSS, p. 209). Even his reflections on how he became a sports writer perfectly situate Bascombe: 'Without knowing I had a natural calling I had hit on a perfect one: to sit in the empty stands of a Florida ballpark and hear the sounds of glove leather and chatter; talk to coaches and equipment managers in the gusty autumn winds of Wyoming; stand in the grass of a try-out camp in a mid-size Illinois grain town and watch footballs sail through the air to bone up on the relevant stats, then go home and back to the office, sit down at my desk and write about it’ (TS, p. 50). 
'Why did I quit writing', Bascombe asks himself, 'Forgetting for the moment that I quit writing to become a sportswriter, which is more like being a businessman, or an oldfashioned traveling salesman with a line of novelty household items, than being a genuine writer, since in so many ways words are just our currency, our medium of exchange with our readers, and there is very little that is ever genuinely creative to it at all - even if you're not much more than a fly-swat reporter, as I'm not' (TS, p. 48). 'Real writing', he continues, 'is something much more complicated and enigmatic than anything usually having to do with sports, though that's not to say a word against sportswriting, which I'd rather do than anything' (p. 48). Bascombe is initially genuinely interested in the lives of the men about whom he writes. He admires their self-possession, writes warmly about them and aspires to a secure and self-contained world of his own. However, the novel proceeds to trace the consequences of his mid-life crisis - the loss of a son, a career, a marriage. He also loses much of his respect for athletes and for sports writing.

Hoping to write a compassionate piece about an ex-footballer who is confined to a wheelchair following a waterskiing accident, he later reaches the conclusion that most athletes are 'never likely to feel the least bit divided, or alienated, or one ounce of existential dread' (TS, p. 68). The athlete possesses ‘a rare selfishness that means he isn’t looking around the sides of his emotions to wonder about alternatives for what he's saying or thinking about' (TS, p. 68). As for sports writers, they "are sometimes damned bad men, and create a life of lies and false tragedies’ (TS, p. 215). He knows he is expected to write something morally uplifting about Herb Wallagher who sits in front of him in his wheelchair: 'The idea being to make us feel sorry enough for Herb, or some idea of Herb, to convince us we're all really like him and tragically involved, when in fact nothing of the kind is true, since Herb isn't even a very likable guy and most of us aren’t in wheelchairs' (TS, p. 215). 
As a sociologist, it is difficult to read The Sportswriter without one's thoughts turning to Marx’s theory of alienation as presented in his early writings. For Marx (1975), alienation is not a human condition; it is the result of specific social relations. Thus, man is alienated from the products of his activity, which belong to another, in Bascombe’s case a newspaper proprietor. This explains Bascombe's acceptance that, in his occupational role, words are just a form currency, a medium of exchange. Man is also alienated from his productive activity insofar as this negates his essential nature. Frank has the potential to do many things but, at this stage in his life, he is first, foremost and arguably exclusively a sportswriter. Man is also alienated from his essential nature i.e. that which makes him truly human as opposed to being a cog in the machine. Frank writes about athletes because that is his job even though increasingly, as is exemplified in his response to Wallagher, he has no empathy for them. According to Goffman (1969: 229), 'to the degree that the individual maintains a show before others that he himself does not believe, he can come to experience a special kind of alienation from self and a special kind of wariness of others'. Finally, man is alienated from others, from the community, and in this respect we see similarities between Bascombe and Waugh, neither of whom appears fully engaged in society writ large.

\section{The athlete}

Henry Skrimshander is also an ordinary Joe as the reader learns on first acquaintance with him: 'He’d been born in Lankton, South Dakota, seventeen and a half years earlier. It was a town of forty-three thousand people, surrounded by seas of corn. His father was a foreman at 
a metalworking shop. His mom worked part-time as an X-ray technician at All Saints. His little sister, Sophie, was a sophomore at Lankton High’ (TAF, p. 7). His fielding takes Skrimshander from a relatively impoverished background to the private Westish College which had experienced little previous success in baseball. Arriving at Westish, he encounters a very different America: ‘This wasn’t Lankton CC; this was college in a movie’ (TAF, p. 14).

Skrimshander is destined for Major League Baseball such are his exploits as a college shortstop. However, he temporarily loses the ability to execute his routine and self-doubt threatens his future. His travails are at the heart of a campus novel which also deals with love, both heterosexual and homosexual. Being a shortstop is central to who he is and how he sees himself: 'Bold nowhere else in life, Henry was bold in this no matter what the coach said, or what his eyebrows expressed, he would jog out to shortstop, pop his fist into Zero’s pocket, and wait. If the coach shouted at him to go to second base, or right field, or home to his mommy, he would keep standing there, blinking and dumb, popping his fist. Finally, someone would hit him a grounder, and he would show what he could do'(TAF, pp. 8-9). Even Skrimshander’s batting was transformative: ‘the Henry who awaited the pitch would be skinny and indefinite, the bat wavering timidly above his bony right elbow, while the Henry who finished the swing, following through with such forceful purpose that the bat head wrapped around and struck him between the shoulder blades, would be chiselled and resolute, his eyes hardened, his curls shaved down to a military half inch. The making of a ballplayer: the production of brute efficiency out of natural genius' (TAF, p. 256). But, as happens to many athletes, his genius deserts him at a crucial part of the season and with it his brute efficiency. He makes mistakes and then finds it impossible to throw at all: 'He walked toward Starblind, who was standing in front of the mound. Starblind was yelling, his mouth moving, white teeth visible, but Henry couldn't hear him. He handed him the ball. As he walked 
toward the dugout he kept his gaze angled up at the blue of the sky' (TAF, p. 323). Yet, in a rather mawkish conclusion, Skrimshander regains his touch: 'The feeling that ripped through Henry was better than that magic IV he'd been served in the Comstock hospital, better than anything he'd felt on a baseball field before' (TAF, p. 512). Why? Because he had made a perfect throw.

Throughout the novel, Harbach alerts us to the fact that the athlete is part of a web of interdependence, - a figuration, if you will - which links, constrains and enables the actions of individuals (Elias, 1978). As Mennell (1977: 100) suggests, 'As people have come to occupy more and more differentiated social positions, they have spun ever more complicated webs of interdependence'. It is within such a web that Skrimshander finds himself. As a consequence, we cannot fully understand this his fate in isolation from those figurations in which he is caught up.

A figurational approach is much less likely to be of analytical value in the case The Universal Baseball Association or The Sportswriter in both of which individual angst is a central motif. What all three novels share, however, is the capacity to make sociologists think sociologically as we read. Just as one would seek to identify emerging themes in a series of interview transcripts or in an extended exercise in media analysis, so it is important to conclude this paper with by indicating the dominant themes that emerge from a reading or 'renting' of these three novels and to articulate the sociological perspectives that are most appropriate for understanding these themes. 


\section{Conclusion}

As Beamish (2010: 29) comments, 'Even though everyone is born into and has grown up within a vast network of social relationships, few people automatically think 'sociologically' - at least not in a manner sociologists would accept'. Saul Bellow was relatively unusual amongst celebrated American novelists having graduated from the University of Chicago in 1937 with majors in sociology and anthropology. This paper does not seek to argue that all novelists think sociologically. But some do whether consciously or not. As C. Wright Mills (1970: 21) observed, although 'their serious work embodies the most widespread definitions of human reality', novelists often possess the sociological imagination. Therefore, because the paper is primarily concerned with the types of data that are of value to sociologists - in this instance, specifically to sociologists of sport - it is argued here that we can and should add certain works of fiction to the more commonly accepted data sources, including interview transcripts, media analysis, archival research, focus groups, participant observation, and other forms of fieldwork. Although this suggestion raises questions about validity, or to put it more bluntly, truth, the approach has been embraced with some degree of enthusiasm in other academic disciplines and, rather more tentatively, by sociologists.

First, these are American novels and the insights they offer are into American sports, above all baseball (the so-called National Pastime) and American football and into sections of American society. Waugh, Bascombe and Skrimshander are white American men with a love of American sports that manifests itself in radically different ways. Their America is not, of course, every American’s America. The signifiers in everyday life which conspire to forge their sense of national identity are not part of every citizen's daily experience. Their very presence in the novels, however, offers insights into what unites and divides the United States. 
A second theme to emerge from the novels is the fragility of physical and mental prowess with specific reference to sport. There is Wallagher's paralysis and Skrimshander's temporary loss of his ability to throw. There are also more generalised reflections on mortality, including Damon Rutherford’s ‘death’ which is pivotal to Coover’s novel. Waugh’s UBA players are concerned with ‘being forced to retire, death and the uselessness that follows upon outliving ones physical prime' (Hume, 1979: 130). Their concerns are, of course, Henry’s own. He ‘cannot face death, yet it fascinates him’ (Hume, 1979: 131). As Bascombe reflects, 'Life will always be without a natural, convincing closure. Except one’. (TSS, p. 372). Some things do, of course, come to their natural conclusion as Bascombe is only too aware: 'I go back again to Herb and write: Herb Wallagher doesn't play ball anymore' (TSS, p. 363). Although younger than Waugh and Bascombe, Skrimshander is made directly aware of the impermanence of human existence by the sudden death of Guert Affenlight, president of Westish College, having been dismissed from his post for 'falling for a bright young boy' (TAF, p. 438) - more traumatic perhaps than the loss of a young man's ability to throw a baseball but both involving the loss of something cherished and integral to the existential self.

Sociologists have been less concerned in recent years than they once were with the issue of retirement form sport. It remains a valid area, however, for sociological enquiry. For Denison (1996: 351), sports retirement can be 'a death of sorts'. Coakley (1983: 8) had taken different view, arguing that 'leaving sport is not inevitably stressful or identity-shaking, nor is it the source of serious adjustment problems'. We can perhaps agree that there is 'both diversity and commonality in the experiences of withdrawing from professional sport' (Swain, 1991: 154). Most relevant to sociology, and to a sociological reading of novels which address retirement and other forms of loss is Coakley’s (1983: 9) assertion that 'the nature of 
the retirement process is primarily grounded in the social structural context in which it occurs'.

Third, the novels force us to confront the limitations of human knowledge of truth and reality: As Schwartz (1987: 148) observes, 'The very process by which Coover establishes uncertainty and our inability to know truth is the same process by which he generates vitality; and that is his great success'. This is true, albeit to a lesser dramatic extent, in Ford and Harbach as well. The stories that the three writers tell are not true but they could be. It is that 'fact' alone that makes them valuable sources of sociological data. First, they allow us to enter worlds that would be difficult, if not impossible, to access using traditional methods of data collection. Second, they are repositories of emerging research themes. Third, they facilitate analysis of themes that are of considerable importance for the sociological understanding of sport.

Last but by no means least, these novels help us to apply and make greater sense of some key sociological concepts, hence their value as teaching aids as well as sources of data. Anomie, alienation, figurations, national identity, retirement from sport, and fundamental methodological questions are all dealt with, either directly or implicitly, in the novels discussed in this paper. Asking our students to read novels rather than, for example, interviewing a dozen of their peers about their sporting interests, might present something of a challenge but it is surely a challenge worth meeting. 


\section{Endnote}

1 The first editions of the novels discussed in this section of the paper are as follows:

The Universal Baseball Association, inc. J. Henry Waugh, PROP (1968)

The Sportswriter (1986)

The Art of Fielding (2011)

The date given in the references is for the edition used in preparing this essay.

\section{References}

Abbario RP (2014) Richard Ford’s Frank Bascombe as an American Everyman. Miscelánea: a journal of english and american studies 50: 49-60.

Alworth DJ (2010) Supermarket Sociology. New Literary History 41 (2): 301-327.

Bairner A (1996) Fields of dreams and nightmares: Images of the sports fan in The Universal Baseball Association, inc. J Henry Waugh, PROP and Shoeless Joe. Irish Journal of American Studies 5: 59-76.

Bairner A (2000) Football and the literary imagination: Sam Hanna Bell's The Hollow Ball and Robin Jenkins' A Would-Be Saint'. Kunnskap om Idrett 4 (4): 30-43.

Bairner A (2009) Memory and the Literary Imagination: Religion, Politics and Football in Robin Jenkins’s The Thistle and the Grail. Sport in History19 (2): 171-189.

Bairner A (2011) Soccer and Society in Eva Menasse’s Vienna. Sport in History 31 (1): 3248 ,

Bateman A (2015) Sport, Literature, Society: Cultural Historical Studies (sport in Global Society - Historical Perspectives). International Journal of the History of Sport 32 (2): 383385.

Beamish R (2010) The Promise of Sociology. The Classical Tradition and Contemporary Sociological Thinking. Toronto: University of Toronto Press. 
Bennett T (2010) Sociology, Aesthetics, Expertise. New Literary History 41 (2): 253-276.

Berger RJ and Quinney R (2005) The narrative turn in social inquiry. In: Berger RJ and Quinney R (eds), Storytelling sociology. Narrative as social inquiry. Boulder, Colorado: Lynne Rienner Publishers, pp. 1-11.

Brooks K (2009) Life is Not a Game: Reworking the Metaphor in Richard Ford's Fiction. Journal of Popular Culture 42 (5): 841-855.

Caldwell RC (1987) Of Hobby-Horses, Baseball, and Narrative: Coover’s Universal Baseball Association. Modern Fiction Studies 33 (1): 161-171.

Chabon M (2008) Summerland. New York: Harper Perennial.

Cheney TAR (2001) Writing creative nonfiction: Fiction techniques for crafting great nonfiction. Berkeley, CA: Ten Speed Press.

Coakley J (1983) Leaving Competitive Sport: Retirement or Rebirth? Quest 35 (1): 1-11.

Coover R (1989) Whatever Happened to Gloomy Gus of the Chicago Bears? London: Minerva.

Coover R (1992) The Universal Baseball Association, inc. J. Henry Waugh, PROP. London: Minerva.

Crosson S (2013) Sport and Film. London: Routledge.

de Certeau M (1988) The Practice of Everyday Life. Berkeley, CA: University of California Press.

Delillo D (1986) End Zone. London: Penguin.

Delillo D (2003) Underworld. New York: Scribner.

Denison J (1996) Sport Narratives. Qualitative Inquiry, 2 (3): 351-362.

Elias N (1978) What is Sociology? London, Hutchinson.

English JF (2010) Everywhere and Nowhere: The Sociology of Literature After "the Sociology of Literature”. New Literary History 41 (2): v-xxiii. 
Ford R (1987). The Sportswriter. London: Flamingo.

Goffman E (1969) The Presentation of Self in Everyday Life. London: Allen Lane.

Goldmann L (1975) Towards a Sociology of the Novel. London: Tavistock Publications.

Harbach C (2012) The Art of Fielding. London: Fourth Estate.

Hill J (2007) Sport and the Literary Imagination: Essays in History, Literature and Sport.

New York: Peter Lang.

Hill J and Williams J (2009) Introduction. Sport in History 29 (2): 127-131.

Hollands RG (1988) English-Canadian Sports Novels and Cultural Production. In: Harvey J and Cantelon H (eds), Not just a game: Essays in Canadian sport sociology. Ottawa:

University of Ottawa Press, pp. 213-226.

Holloway R (2012) Leaving Alexandria. A memoir of faith and doubt. Edinburgh: Canongate Books.

Horton P (2012) Tumultuous Text: The Imagining of Australia Through Literature, Sport and Nationalism from Colonies to the Federation. International Journal of the History of Sport, 29 (12): 1669-1686.

Hughson J (2010) The cultural legacy of Olympic posters. Sport in Society, (13 (5): 740-759.

Hughson J (2011) Not Just Any Wintry Afternoon in England; the curious contribution of C. R. W. Nevinson to 'football art'. International Journal of the History of Sport, 28 (18): 26702687.

Hume K (1979) Robert Coover's Fiction: The Naked and the Mythic. NOVEL: A Forum on Fiction 12 (2): 127-148.

Izzo J-C (2013) Garlic, mint, and sweet basil. Essays on Marseilles, Mediterranean cuisine, and noir fiction. New York: Europa Editions.

Jenkins C and Green M (eds) (1981) Sporting Fictions. Conference Proceedings. Birmingham: Centre for Contemporary Cultural Studies and the Department of Physical Education in the University of Birmingham. 
Johnes M (2007) Texts, audiences, and postmodernism: The novel as source in sport history. Journal of Sport History 34 (1): 121-133.

Johnson D (2008) “A Ball As Big As the Moon”: Sports in Richard Ford’s Fiction. Aethlon XXV (1): 45-57.

Kane MJ (1998) Fictional Denials of Female Empowerment: A Feminist Analysis of Young Adult Sports Fiction. Sociology of Sport Journal 15 (3): 231-262.

Kesavan M (2012) Cricket and the Nation: A Novelist Reads Three Recent Cricket Novels. International Journal of the History of Sport 29 (12): 1805-1814.

Koch T (1998) Story telling; is it really research? Methodological issues in nursing research 28 (6): 1182-1190.

Maitland S (2012) The greatest pleasure I know. Saturday Guardian Review, 22 September: 14-15.

Malamud B (1967) The Natural. London: Penguin.

Marx K (1975) Early Writings. London: New Left Review.

McGowan L (2015) Marking out the pitch: a historiography and taxonomy of football fiction. Soccer and Society 16 (1): 76-97.

McLaughlin R (2013) After the Revolution: US Postmodernism in the Twenty-First Century. Narrative 21 (3): 284-295.

Mennell S (1977) "Individual” action and its "social” consequences in the work of Norbert Elias. In: Gleichmann PR, Goudsblom J, Korte H and Elias N (eds), Human Figurations. Essay for Norbert Elias. Amsterdam: Amsterdams Sociologisch Tijdschrift, pp. 99-109. Merton RK (1938) Social Structure and Anomie. American Sociological Review 3 (5): 672682.

Mills CW (1970) The Sociological Imagination. Harmondsworth: Pelican.

Mizruchi SL (1998) The Science of Sacrifice. American Literature and Modern Social Theory. Princeton: Princeton University Press. 
Plimpton G (1988) The Curious Case of Sidd Finch. London: Bloomsbury.

Putnam RD (2001) Bowling Alone. The Collapse and Revival of American Community. New York: Touchstone.

Queenan J (2010) Closing time. A memoir. London: Picador.

Rinehart R (1998) Fictional Methods in Ethnography: Believability, Specks of Glass, and Chekhov. Qualitative Inquiry, 4 (2): 200-224.

Rinehart R (2015) Surf Film, Then \& Now: The Endless Summer Meets Slow Dance. Journal of Sport and Social Issues, forthcoming.

Roth P (1991) The Great American Novel. London: Vintage.

Ryan D (2012) Fair Game? James Joyce, Sean O’Casey, and the Contesting of Irish Sport. Études irlandais 37 (1): 105-145 http://etudesirlandaises.revues.org/3016 Accessed 9 December 2014.

Schuster JM (2012) The Might Have Been. New York: Ballantine Books.

Schwartz RA (1987) Postmodernist Baseball. Modern Fiction Studies 33 (1): 135-149.

Shivani A (2014) Chad Harbach's The Art of Fielding: College Baseball as an Allegory for American National Greatness. The Cambridge Quarterly 43 (1):39-59.

Smith B, McGannon KR and Williams TL (2016) Ethnographic creative nonfiction. Exploring the whats, whys and hows. In: Molnar G and Purdy LG (eds), Ethnographies in Sport and Exercise Research. Oxford: Routledge, pp. 59-73.

Smith JE (2010) The Comeback Season. New York: Simon and Schuster.

Sparkes AC and Smith B (2013) Qualitative Research Methods in Sport, Exercise and Health: From Process to Product. London: Routledge.

Swain DA (1991) Withdrawal From Sport and Schlossberg's Model of Transitions. Sociology of Sport Journal 8 (2): 152-160. 
Tadié A (2010) The Fictions of (English) Cricket: From Nation to Diaspora. International Journal of the History of Sport 27 (4): 690-711.

Whannel G ( 2002).Media Sport Stars. Masculinities and Moralities. London: Routledge. 